\title{
First confirmed record for Peru of Diclidurus scutatus Peters, 1869 (Chiroptera: Emballonuridae)
}

\author{
Mario Escobedo ${ }^{1}$ and Paúl M. Velazco ${ }^{2^{*}}$ \\ 1 Pasaje Simón Bolívar N 142. Iquitos, Perú. \\ 2 American Museum of Natural History, Department of Mammalogy. Central Park West at 79th Street. New York, NY 10024, USA. \\ * Corresponding author. E-mail: pvelazco@amnh.org
}

\begin{abstract}
Diclidurus scutatus Peters, 1869, is known from Venezuela, Guyana, Surinam, French Guiana, Brazil, Ecuador, and Peru. In Peru D. scutatus was previously known from a single specimen without a specific locality. Here we report the first record of $D$. scutatus from a known locality for Peru. We also provide an updated distribution map for the species.
\end{abstract}

The genus Diclidurus Wied-Neuwied, 1820 includes four species grouped into two subgenera: Diclidurus for albus, ingens, and scutatus and Depanycteris for isabellus (Hood and Gardner 2008; Simmons 2005). The genus is distributed from western Mexico, southeastward to eastern Brazil (Hood and Gardner 2008). Members of this genus are diagnosed by the presence of relatively long, soft, whitish to pale brownish pelage; a small first upper premolar not in contact with the second; postorbital processes broad, nearly obliterated by markedly broadened supraorbital ridges; rostrum distinctly and deeply dished; and the presence of a large and conspicuous glandular area on the uropatagium (especially prominent in males during the breeding season) at, and posterior to, the place where the tail protrudes from the membrane (Jones and Hood 1993).

There are only two species of Diclidurus reported to occur in Peru: D. albus Wied-Neuwied, 1820 distributed from western Mexico southward to eastern Bolivia, and Trinidad (Hood and Gardner 2008; Vargas Espinoza 2007) characterized by having a forearm length ranging from 60-70 mm and lacking a palatine foramen; and D. scutatus Peters, 1869 known from Venezuela, Guyana, Surinam, French Guiana, Brazil, Ecuador, and Peru (Jones and Hood 1993; Albuja 1999) characterized by having a forearm shorter than $60 \mathrm{~mm}$ and a large palatine foramen that is confluent with a posterior palatal emargination (Jones and Hood 1993). Both species are represented by single specimens deposited at the American Museum of Natural History, New York, USA (AMNH), collected by Abram Andi in different years. The specimen of D. albus (AMNH 99310) is an adult of undetermined sex preserved as skin and skull collected in Parinari, Loreto (04³4' S, $74^{\circ} 26^{\prime}$ W, Figure 1 ) on May $30^{\text {th }} 1929$. The specimen of D. scutatus (AMNH 99309) is an adult of undetermined sex preserved as skin and skull, without any indication of precise locality other than "Peru," collected on January $8^{\text {th }} 1924$.

Herein we report the first vouchered record of Diclidurus scutatus with a precise locality in Peru and provide an updated distribution map for the species. This specimen, an adult female, MUSM 37068 (Figure 2), was collected at the mouth the Yavarí river on Lago Preto, Lago Preto Conservation Concession, Loreto, Peru (04³0' S, $71^{\circ} 43^{\prime}$ W, Figure 1) on May 29, 2007 at 19:30 h. The habitat at the site of capture is a river bank forest with clay soils and an open understory characterized by the presence of some Cecropia sp., Helicona sp., and Piper sp. The height of the forest canopy was $18 \mathrm{~m}$ and characterized by the presence of Bactris spp., Cecropia sp., and Inga sp. This bat was collected during a full moon night in a mistnet set 10 meters above ground. The specimen was deposited in the mammal collection of the Museo de Historia Natural de la Universidad Nacional Mayor de San Marcos (MUSM) in Lima, Peru. Standard external measurements (in $\mathrm{mm}$ ) are as follows: length of tail, 13.0; length of tibia, 20.0; length of hind foot, 10.0; length of forearm, 58.0; length of ear (tragus), 15.0 (6.0). Selected cranial and forearm measurements are provided in Table 1.

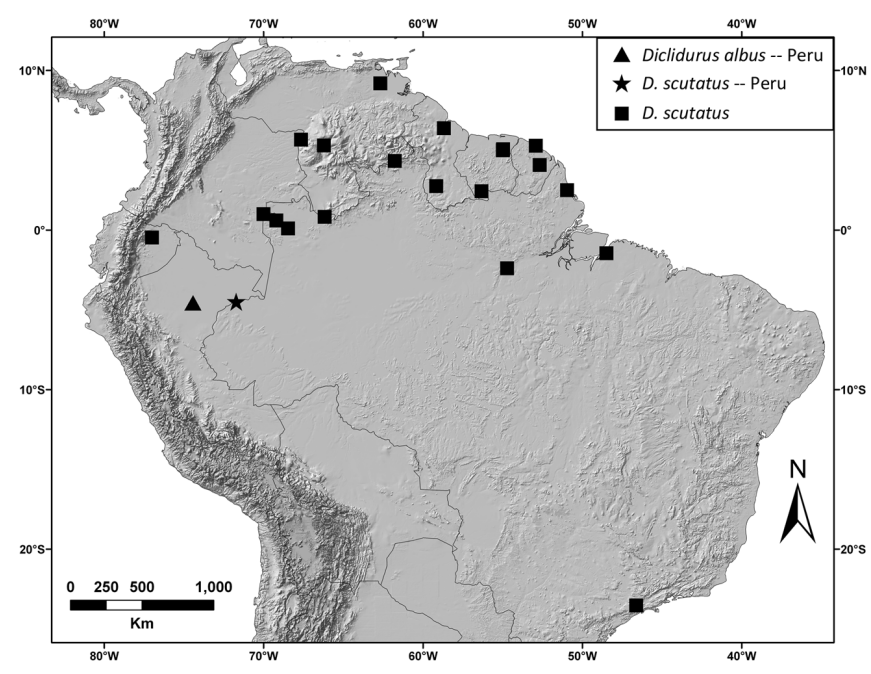

FIgURE 1. Geographic distribution of Diclidurus scutatus and the new record in Peru (star) and the Peruvian record of D. albus (triangle). 
The following list includes all other localities where Diclidurus scutatus has been recorded throughout its distribution. The following institutional abbreviations are used on the list: AMNH (American Museum of Natural History, New York, USA), FMNH (Field Museum of Natural History, Chicago, USA), MUSM (Museo de Historia Natural de la Universidad Nacional Mayor de San Marcos, Lima, Peru), and ROM (Royal Ontario Museum, Toronto, Canada). BRAZIL: Amapá: Colônia Torrão, Calçoene (Piccinini 1974). Amazonas: Jauareté, Rio Uaupés (= Iauaretê) (Piccinini 1974); Taracuá, (= Taraquá), Rio Negro (= Rio Vaupés) (Vieira 1942). Pará: Para (= Belém) (Thomas 1920); Santarém, Piquiatuba, Tapajós River (AMNH 95779). São Paulo: São Paulo (Sodré and Uieda 2006). COLOMBIA: Vaupés: Lower Río Apaporis, Yay Gojes (FMNH 88234-88235). ECUADOR: Orellana: Coca, Campo Petrolero Sacha Norte 1 (Albuja 1999). FRENCH GUIANA: Sinnamary: Paracou, near Sinnamary (Simmons and Voss 1998). Régina: Les Nouragues (Brosset and CharlesDominique 1991). GUYANA: Cuyuni-Mazaruni: Kartabo Point, Cuyuni River (AMNH 142908). Upper Takutu-Upper Essequibo: Rupununi, Marurawaunawa Village, Ow-wi-dywau, Ishi Wau Head, Near Marurawaunowa (ROM 38505). PERU: Loreto: mouth of Lago Preto, Yavari River (MUSM 37068). SURINAME: Brokopondo: Afobaka, on Suriname River, northern shore of Brokopondo Lake (Husson
1978); Brokopondo (Husson 1978). Brokopondo?: Upper Suriname River (Husson 1978). Nickerie: Alalapadu, $322 \mathrm{~km}$ S. of Paramaribo (ROM 34575). VENEZUELA: Amazonas: Cerro Neblina Base Camp (Gardner 1988); Puerto Ayacucho (Handley 1976); San Juan, Río Manapiare, $163 \mathrm{Km}$ ESE Puerto Ayacucho (Handley 1976). Bolívar: Icabarú (Handley 1976). Monagas: Laguna Guasacónica (Linares and Rivas 2003).

Even though Diclidurus albus and D. scutatus have been found in only a few localities, the IUCN lists them as Least Concern because of their wide distribution. Therefore, these species are unlikely to be declining fast enough to qualify for inclusion in any of the threat categories in the near future (Lim et al. 2008; Sampaio et al. 2008).

After decades of continuous bat research in Peru, the only two previous records for Diclidurus were collected in the 1920's. Diclidurines are rapid fliers active at treetop levels or in open areas over water (Kalko et al. 1996; Lim et al. 1999; Ochoa G. et al. 2008). We believe that the use of a variety of uncommon practices, such as using shotguns, aerial nets, and acoustic monitoring methods in bat surveys in Peru will be necessary to improve our knowledge of the biology and distribution of this group of bats, which are not easily caught in nets because of their flight behavior.

TABLE 1. Measurements (mm) of Diclidurus albus and D. scutatus.

\begin{tabular}{|c|c|c|c|c|c|}
\hline \multirow[t]{2}{*}{ MEASUREMENTS } & \multicolumn{2}{|c|}{ Diclidurus albus } & \multicolumn{3}{|c|}{ Diclidurus scutatus } \\
\hline & Range $^{a}$ & AMNH 99310 & Range $^{b}$ & AMNH 99309 & MUSM 37068 \\
\hline Forearm length & $63.0-69.2$ & 61.1 & $51.0-58.9$ & 54.0 & 58.0 \\
\hline Greatest length of skull & $17.0-19.6$ & -- & $15.3-15.7$ & -- & -- \\
\hline Zygomatic breadth & $11.9-12.7$ & -- & $10.6-11.5$ & 10.2 & -- \\
\hline Least breadth of postorbital constriction & $5.5-5.9$ & 5.2 & $4.3-5.3$ & 4.8 & -- \\
\hline Braincase breadth & $8.9-9.9$ & -- & $8.3-8.5$ & 8.4 & -- \\
\hline Length of maxillary toothrow & $7.3-8.7$ & 7.5 & $6.3-7.5$ & 6.5 & -- \\
\hline Mastoid breadth & $9.8-10.2$ & -- & $9.2-9.3$ & -- & -- \\
\hline Breadth across canines & $5.6-6.2$ & 4.2 & $3.8-4.0$ & 3.9 & -- \\
\hline Breadth across third upper molars & $8.0-9.0$ & 8.0 & $7.1-7.4$ & 7.2 & -- \\
\hline
\end{tabular}

a Measurements provided by Jones (1966), Ojasti and Linares (1971), Starrett and Casebeer (1968), and Villa-R. and Ramirez-P. (1968).

b Measurements provided by Albuja (1999), Husson (1962), and Sodré and Uieda (2006) and from the following specimens R0M 34575 , 38505 and FMNH 88234-88235.

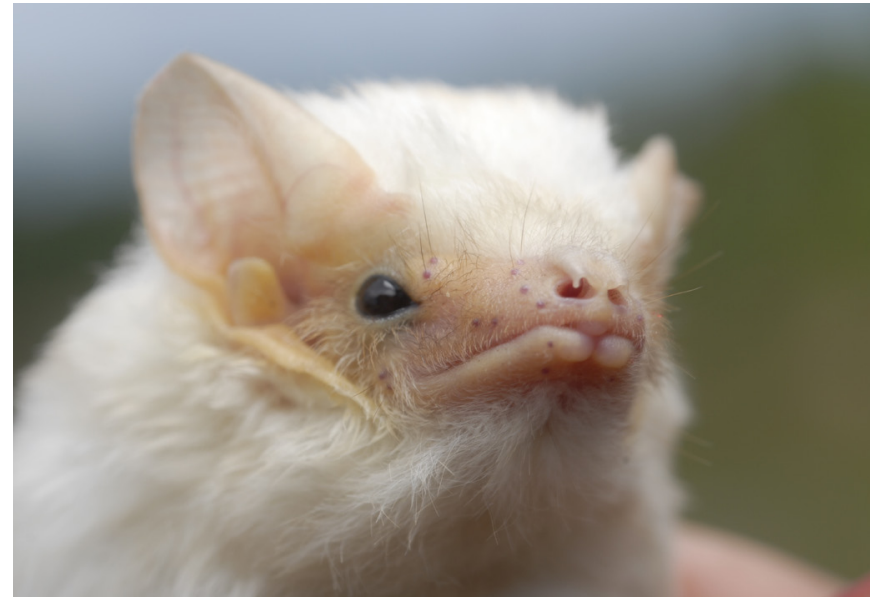

FIGURE 2. Live photograph (MUSM 37068 - 9 ) of the little ghost bat, Diclidurus scutatus, collected at the mouth of Lago Preto, Lago Preto Conservation Concession, Yavarí river, Loreto, Peru. Photo: Mark Bowler.
ACKNOWLEDGMENTS: We want to thank all the personnel at Durrell Institute of Conservation and Ecology of the University of Kent especially the expedition leader, Richard Bodmer. We are grateful to Mark Bowler for allowing us to use his photograph of the live individual, to our guide Edwin Pinedo, the students Mark McEnnerney and David William for their help during the expedition. Alfred Gardner, Eliécer Gutiérrez and Kerry A. Kline read an early draft of this report and made helpful suggestions for its improvement, for which we are grateful.

\section{Literature Cited}

Albuja V., L. 1999. Murciélagos del Ecuador. 2nd ed. Quito, Ecuador: Cicetrónica Cía. Ltda. Offset. 288 p.

Brosset, A. and P. Charles-Dominique. 1991 [1990]. The bats from French Guiana: A taxonomic, faunistic and ecological approach. Mammalia 54: 509-560.

Gardner, A.L. 1988. The mammals of Parque Nacional Serranía de la Neblina, Territorio Federal Amazonas, Venezuela; p. 695-765. In C. Brewer-Carias (ed.). Cerro de la Neblina. Resultados de la Expedición 1983-1987. Caracas: Editorial Sucre.

Handley, C.O., Jr. 1976. Mammals of the Smithsonian Venezuelan Project. Brigham Young University Science Bulletin, Biological series 20(5): 1-89. 
Hood, C. and A.L. Gardner. 2008 [2007]. Family Emballonuridae Gervais, 1856; p. 188-207. In A.L. Gardner (ed.). Mammals of South America. Marsupials, xenarthrans, shrews, and bats. Chicago: University of Chicago Press.

Husson, A.M. 1962. The bats of Suriname. Zoologische Verhandelingen, Rijksmuseum van Natuurlijke Historie te Leiden 58: 1-282, 30 pls.

Husson, A.M. 1978. The mammals of Suriname. Zoölogische Monographieën van het Rijksmuseum van Natuurlijke Historie No. 2. Leiden: E. J. Brill. xxxiv +569 p.

Jones, J.K., Jr. 1966. Bats from Guatemala. University of Kansas Publications, Museum of Natural History 16: 439-472.

Jones, J.K., Jr. and C.S. Hood. 1993. Synopsis of South American bats of the family Emballonuridae. Occasional Papers, Museum of Texas Tech University 155: 1-32.

Kalko E.K.V., C.O. Handley Jr. and D. Handley. 1996. Organization, diversity, and long-term dynamics of a Neotropical bat community; p. 503-553. In M.L. Cody and J.F. Smallwood (ed.). Long-term studies in vertebrate communites. Los Angeles: Academic Press.

Lim, B., M.D. Engstrom, R.M. Timm, R.P. Anderson, and L.C. Watson. 1999. First records of 10 bat species in Guyana and comments on diversity of bats in Iwokrama Forest. Acta Chiropterologica 1: 179-190.

Lim, B., B. Miller, F. Reid, J. Arroyo-Cabrales, A.D. Cuarón and P.C. de Grammont. 2008. Diclidurus albus. In IUCN 2011. IUCN Red List of Threatened Species. Version 2011.1. Electronic Database accessible at $<$ www.iucnredlist.org>. Captured on 11 October 2011.

Linares, O.J. and B. Rivas A. 2003. Mamíferos del sistema deltaico (delta de Orinoco-golfo de Paria), Venezuela. Memorias de la Fundación La Salle de Ciencias Naturales 159-160: 27-104.

Ochoa G., J., J. Sánchez H., F. García and J.A. Clavijo. 2008. An undescribed behavior of the Isabelle's ghost bat (Diclidurus isabellus), with distributional notes in Venezuela. Memoria de la Fundación La Salle de Ciencias Naturales 168(70): 141-148.

Ojasti, J., and 0.J. Linares. 1971. Adiciones a la fauna de murciélagos de Venezuela con notas sobre las especies del género Diclidurus (Chiroptera). Acta Biologica Venezuelica 7: 421-441.

Piccinini, R.S. 1974. Lista provisória dos quirópteros da coleção do Museu Paraense Emílio Goeldi (Chiroptera). Boletim do Museu Paraense Emílio Goeldi, zoologia 77: 1-32.
Sampaio, E., B. Lim and S. Peters. 2008. Diclidurus scutatus. In IUCN 2011. IUCN Red List of Threatened Species. Version 2011.1. Electronic Database accessible at <www.iucnredlist.org>. Captured on 11 October 2011.

Simmons, N.B. 2005. Order Chiroptera; p. 312-529. In D.E. Wilson and D.M. Reeder (ed.). Mammal species of the World. A taxonomic and geographic reference. 3rd edition. Baltimore: The Johns Hopkins University Press.

Simmons, N.B., and R.S. Voss. 1998. The mammals of Paracou, French Guiana: A Neotropical lowland rainforest fauna, Part 1. Bats. Bulletin of the American Museum of Natural History 237: 1-219.

Sodré, M.M., and W. Uieda. 2006. First record of the ghost bat Diclidurus scutatus Peters (Mammalia, Chiroptera, Emballonuridae) in São Paulo city, Brazil. Revista Brasileira de Zoologia 23: 897-898.

Starrett, A. and R.S. Casebeer. 1968. Records of bats from Costa Rica. Los Angeles County Museum Contributions in Science 148: 1-21.

Thomas, 0. 1920. On mammals from the lower Amazons in the Goeldi Museum, Para. Annals and Magazine of Natural History (9) 6: 266283.

Vargas Espinoza, A. 2007. Familia Emballonuridae (Gervais, 1855); p. 158-173. In L.F. Aguirre (ed.). Historia Natural, Distribucion y Conservacion de los Murciélagos de Bolivia. Bolivia: Editorial Centro de Ecología y Difusion Simón I. Patiño.

Vieira, C.O. da C. 1942. Ensaio monográfico sobre os quirópteros do Brasil. Arquivos de Zoologia do Estado de São Paulo 3: 219-471.

Villa-R., B. and J. Ramírez-P. 1968. Diclidurus virgo Thomas, el murcielago blanco, en la costa de Nayarit. Anales del Instituto de Biología, Universidad Nacional Autónoma de México, serie Zoológica 39(1): 155-158.

RECEIVED: December 2011

ACCEPTED: March 2012

Published ONLINE: June 2012

EDITORIAL RESPONSIBILITY: Marcelo Rodrigues Nogueira 